Brazilian Journal

of Chemical

ISSN 0104-6632

Printed in Brazil

Engineering

www.scielo.br/bjce

Vol. 35, No. 02, pp. 477 - 488, April - June, 2018

dx.doi.org/10.1590/0104-6632.20180352s20160502

(cc) BY

\title{
ETHANOL PRECIPITATION AS A DOWNSTREAM PROCESSING STEP FOR CONCENTRATION OF XYLANASES PRODUCED BY SUBMERGED AND SOLID-STATE FERMENTATION
}

\author{
Max A. L. Costa ${ }^{1}$, Cristiane S. Farinas ${ }^{2,3}$ and Everson A. Miranda ${ }^{1 *}$ \\ ${ }^{1}$ School of Chemical Engineering, State University of Campinas, 13083-852, Campinas, SP, Brazil \\ ${ }^{2}$ Embrapa Instrumentação, Rua XV de Novembro 1452, 13560-970, São Carlos, SP, Brazil \\ ${ }^{3}$ Graduate Program of Chemical Engineering, Federal University of São Carlos, 13565-905, São \\ Carlos, SP, Brazil
}

(Submitted: August 21, 2016; Revised: February 12, 2017; Accepted: March 2, 2017)

\begin{abstract}
Xylanases have applications in different industries, being produced by microbial cultivations using submerged (SmF) or solid-state fermentation (SSF). Precipitation stands out as a potential method for the concentration of xylanases, especially with the use as ethanol as the precipitant due to its compatibility with the biorefinery concept. This paper presents a comparative laboratory scale study of ethanol precipitation of xylanases produced by Aspergillus niger cultivated under SSF and SmF. Precipitation conditions were selected according to a central composite design. Statistical analysis showed a significant effect of $\mathrm{pH}$ on the recoveries of total protein and xylanase activity. The kinetic profiles showed that a relatively short period of time (up to 15 min) was sufficient to recover most of the xylanase activity precipitated under the selected conditions. Xylanase recoveries of 65 and $79 \%$ were achieved for the SSF and SmF enzymatic complexes, respectively.
\end{abstract}

Keywords: Aspergillus niger; downstream processing; ethanol precipitation; xylanase.

\section{INTRODUCTION}

Hemicellulose is the second most abundant renewable natural polymer and, together with lignin and cellulose, forms the highly complex plant cell wall structure (Pauly et al., 2013; Shallom and Shoham, 2003; Wong et al., 1988). Hemicelluloses are branched heteropolysaccharide complex compounds made of D-glucose, D-galactose, D-mannose, D-xylose, L-arabinose, D-glucuronic acid and 4-O-methyl-glucuronic acid. Removal of their side chains is required to increase the rate of enzymatic degradation (Santos et al., 2012). Xylan, the major

*Corresponding author. E-mail: everson@feq.unicamp.br component of hemicellulose, consists of a backbone of $\beta$-xylopyranose residues joined by $\beta$-1,4-glycosidic linkages, decorated with acetyl, arabinofuranosyl, and glucuronic or 4-O-methylglucuronic acid groups (Saha, 2003). The endo-1,4- $\beta$-xylanase (xylanase) enzyme cleaves the $\beta$-1,4-glycosidic linkage between xylose residues in the backbone of xylan and is essential for the depolymerization of hemicellulose (Dodd and Cann, 2009). Xylanase enzymes have applications in the food industry, as well as in other technological sectors such as pulp and paper production (Collins et al., 2005). In the biofuels sector, the action of xylanases improves cellulose conversion during the hydrolysis of biomass for cellulosic 
ethanol production by removing hemicellulose and increasing the accessibility of the substrate to cellulase enzymes (Gao et al., 2011; Kumar and Wyman, 2009). On an industrial scale, xylanases are mainly produced by filamentous fungi of the genera Aspergillus and Trichoderma (Park et al., 2002), using submerged fermentation (SmF) or solid-state fermentation (SSF). About $80-90 \%$ of all xylanases are produced in submerged culture (Polizeli et al., 2005). Nevertheless, the use of SSF is particularly advantageous for enzyme production by filamentous fungi, because it simulates the natural habitat of these microorganisms and, from an environmental perspective, enables the use of agroindustrial residues as sources of carbon and energy for microorganism growth and enzyme production (Farinas, 2015; Holker and Lenz, 2005).

Production of xylanases using strains of Aspergillus under both SmF and SSF have been widely reported (Betini et al., 2009; Chapla et al., 2010; Chipeta et al., 2008; Fang et al., 2010; Ghanem et al., 2000; Pirota et al., 2013; Venegas et al., 2013), as these fungi exhibit favorable fermentation characteristics, including high protein secretion rates and the ability to produce a wide range of extracellular enzymes (de Vries, 2003). However, most of the aforementioned studies have mainly focused on the enzyme production step, with evaluation of different fungal strains and the effects of the operational conditions used in the cultivation process. Given that both SSF and SmF cultivations usually result in enzymatic complexes at concentration levels too low for immediate application in industrial processes, there is an urgent need for studies focusing on downstream processing (DSP) unit operations. The concentration step is especially necessary in the development of processes for on-site production of enzymes, in order to improve the catalytic efficiency of the enzymatic cocktails.

The choice of DSP unit operations is a major challenge in defining a biotechnological process, because loss of the bioproduct in the multiple operations of separation, concentration, and purification can compromise the efficiency of the entire process. Furthermore, cost reduction is a priority in the case of industrial enzymes. Given these considerations, the precipitation technique can be very effective in concentrating xylanase preparations, especially since high purity (which is typically achieved using chromatographic processes) may not be required for applications in areas such as the biofuels sector (Farinas et al., 2011). Although there are numerous reports concerning the isolation and purification of xylanases, most only describe the precipitation step for a single specific condition, usually for the purposes of biochemical characterization (Ahmad et al., 2013; Bokhari et al., 2009; Chanwicha et al., 2015; Lu et al., 2008; Mander et al., 2014; Ninawe et al., 2008).

From a bioprocess engineering standpoint, identification of the optimal operational conditions for the precipitation of proteins involves the study of different process variables, including the type and concentration of the precipitant, temperature, aging time, agitation, $\mathrm{pH}$, and so forth. In terms of the precipitant, the use of a renewable material such as ethanol is especially attractive, because it complies with the biorefinery concept (Kamm and Kamm, 2004), since it is a bioproduct of the biorefinery itself, available in site at low cost. Ethanol is one of the most important industrial precipitants, and its use can lead to a favorable balance between the solubility effect and an appropriate hydrophilicity, minimizing protein denaturation (Golunski et al., 2011). However, in order to achieve high precipitation recovery of xylanase activity, a relatively high ethanol concentration $(\geq 80 \%, v / v)$ is usually required (Fadel, 2001; Marino et al., 2015; Varma et al., 1999). This increases cost as well as the risk of protein denaturation, hence compromising the feasibility of the DSP. Therefore, a systematic investigation of the precipitation operational parameters has to be undertaken to enable this process to be effectively applied for each specific system.

Considering the industrial importance of xylanase enzymes, together with the high availability and low cost of ethanol, the purpose of this study was to carry out a systematic comparative evaluation of the precipitation with ethanol of xylanases produced by A. niger under SSF and SmF, and to determine the feasibility of applying this process as a cost-effective DSP unit operation. Prior to the precipitation studies, preliminary evaluations were made of the thermal and $\mathrm{pH}$ stabilities of the xylanases from both sources, together with determination of the cloud points following ethanol addition. Experimental design methodology was then used as a tool to investigate the effects of ethanol concentration and $\mathrm{pH}$ on xylanase precipitation recovery.

\section{MATERIALS AND METHODS}

\section{Microorganism}

The Aspergillus niger A12 strain was obtained from Embrapa Food Technology (Rio de Janeiro, Brazil) (Couri and deFarias, 1995). The strain was kept at -18 
${ }^{\circ} \mathrm{C}$ and was activated by incubation on slants of potato dextrose agar (PDA) medium for four days at $32{ }^{\circ} \mathrm{C}$. Suspensions of spores were prepared by the addition of $10 \mathrm{~mL}$ of Tween $80(0.3 \%, \mathrm{v} / \mathrm{v})$. Spore concentrations were determined using a Neubauer chamber.

\section{Solid-state fermentation (SSF)}

The solid-state fermentation cultivations were carried out in $250 \mathrm{~mL}$ conical flasks containing $5 \mathrm{~g}$ of dry wheat bran sterilized by autoclaving at $121{ }^{\circ} \mathrm{C}$ for $15 \mathrm{~min}$. The moisture content of the medium was then adjusted by the addition of $3 \mathrm{~mL}$ of a nutrient medium (Mandels and Sternberg, 1976). A concentration of $10^{7}$ spores/g of dry solid substrate was added, and the cultivations were conducted under static conditions at $32{ }^{\circ} \mathrm{C}$ for $72 \mathrm{~h}$. The enzymes were extracted by the addition of $1: 10(\mathrm{w} / \mathrm{v}$, mass of dry wheat bran to volume of extraction solution) $0.05 \mathrm{~mol} / \mathrm{L}$ sodium acetate buffer solution ( $\mathrm{pH} 4.5)$ and agitating the flasks in a shaker at $200 \mathrm{rpm}, 32{ }^{\circ} \mathrm{C}$, for $30 \mathrm{~min}$. The final enzymatic extracts were filtered, centrifuged at 12,900 $g$ for $10 \mathrm{~min}$, and kept frozen at $-18{ }^{\circ} \mathrm{C}$ prior to the analytical assays. All the cultivation experiments were carried out in triplicate, and the data were calculated as means \pm standard deviations.

\section{Submerged fermentation $(\mathrm{SmF})$}

In the submerged fermentation procedure, the preculture was initiated with a $10^{7}$ spores $/ \mathrm{mL}$ conidial suspension, in $250 \mathrm{~mL}$ conical flasks containing $50 \mathrm{~mL}$ of nutrient medium (Mandels and Sternberg, 1976) enriched with $30 \mathrm{~g} / \mathrm{L}$ of glucose. The incubation was carried out for $50 \mathrm{~h}$ in a shaker at $32{ }^{\circ} \mathrm{C}$, with stirring at $200 \mathrm{rpm}$. Aliquots $(10 \mathrm{~mL})$ of preculture suspension were transferred to $250 \mathrm{~mL}$ conical flasks containing $40 \mathrm{~mL}$ of the culture medium supplemented with 10 $\mathrm{g} / \mathrm{L}$ of glucose and $1 \%(\mathrm{w} / \mathrm{v})$ of wheat bran sterilized by autoclaving at $121{ }^{\circ} \mathrm{C}$ for $15 \mathrm{~min}$. The cultivations were performed for $72 \mathrm{~h}$ in a shaker at $32{ }^{\circ} \mathrm{C}$ and $200 \mathrm{rpm}$. The cultivation broth was then filtered, centrifuged at $12,900 \mathrm{~g}$ for $10 \mathrm{~min}$, and the resulting crude enzymatic extract was stored at $-18{ }^{\circ} \mathrm{C}$ prior to further analysis. All the cultivation experiments were performed in triplicate, and the data were calculated as means \pm standard deviations.

\section{Enzyme thermal and pH stability}

The thermal stability of the xylanase was evaluated by measuring the residual enzymatic activity after incubation of $1.0 \mathrm{~mL}$ of the crude fermentation broth $(\mathrm{SmF})$ or extract $(\mathrm{SSF})$ with $1.0 \mathrm{~mL}$ of a 0.2
mol/L sodium acetate $\mathrm{pH} 5.0$ buffer solution (for $\mathrm{pH}$ adjustment) at 15,30 , and $45^{\circ} \mathrm{C}$ for up to $180 \mathrm{~min}$. For the $\mathrm{pH}$ stability study, the $\mathrm{pH}$ of the enzyme preparations was adjusted to $\mathrm{pH} 3.0,4.0,5.0$, and 6.0 using $0.2 \mathrm{~mol} / \mathrm{L}$ sodium citrate buffer, and to $\mathrm{pH}$ $6.0,7.0$, and 8.0 using $0.2 \mathrm{~mol} / \mathrm{L}$ sodium phosphate buffer. These $\mathrm{pH}$-adjusted enzyme preparations (1.0 $\mathrm{mL}$ volumes) were incubated at $30{ }^{\circ} \mathrm{C}$ for a total period of $180 \mathrm{~min}$. In each of these studies, sampling was performed after time intervals of $10,30,60,120$, and $180 \mathrm{~min}$. At the end of the incubation period, the samples were centrifuged at $12,900 \mathrm{~g}$ for 10 min and the supernatants were used for total protein concentration and xylanase activity analyses. All the experiments were carried out in triplicate, and the data were calculated as means \pm standard deviations. The data obtained were used to do linear fits for protein concentration and xylanase activity $\left(\left.\operatorname{Prot}\right|_{\mathrm{t}}\right.$ and Activ $\left.\right|_{\mathrm{t}}$, respectively) as a function of time.

\section{Cloud point determination}

For determination of the cloud point (the minimum concentration of ethanol added to the enzyme preparation required to cause visual clouding of the solution), the $\mathrm{pH}$ of the enzyme preparation $(2.0 \mathrm{~mL}$ volume) was adjusted to 5.5 by adding 9 volumes of a $2.0 \mathrm{~mol} / \mathrm{L}$ sodium citrate $\mathrm{pH} 5.5$ buffer in a $15 \mathrm{~mL}$ Falcon tube. The tube was weighed and then placed in an ice bath, followed by dropwise addition of ethanol at $-7{ }^{\circ} \mathrm{C}$, at a flow rate of $1 \mathrm{~mL} / \mathrm{min}$, until clouding was visually detected. The mixture was allowed to rest for $10 \mathrm{~min}$, and if the turbidity was maintained, the tube was weighed again in order to determine the final mass of ethanol required to reach the cloud point. Ten replicate determinations were performed for each enzyme preparation (SSF and SmF).

\section{Experimental design}

A full factorial design followed by response surface analysis was used to evaluate the effects of two variables $(\mathrm{pH}$ and ethanol concentration, individually and in interaction) on the precipitation of the xylanases. The experimental design selected was a central composite design (CCD) comprising 11 runs, corresponding to four cube points, four axial points, and three central points, with the experiments carried out in random order. The $\mathrm{pH}$ varied from 3.4 to 7.6 and the ethanol concentration varied from 78 to $92 \%(\mathrm{v} / \mathrm{v})$ (a preliminary study showed that, below $70 \%$ ethanol, recovering of activity and protein in the precipitate were too low for precise quantification). The dependent 
variables (responses) were xylanase activity recovery, total protein recovery, specific activity, and purification factor. Statistica v. 8.0 software (Statsoft) was used to analyze the experimental data, perform analysis of variance (ANOVA) calculations, and plot the response surfaces.

For this entire set of precipitation experiments, the $\mathrm{pH}$ of the enzyme preparations was first adjusted to the values established in the experimental design, using $2.0 \mathrm{~mol} / \mathrm{L}$ sodium citrate buffer at a 1:9 (v/v) sample:buffer ratio. A $1.0 \mathrm{~mL}$ volume of each sample was transferred to a $50 \mathrm{~mL}$ Falcon tube. The tubes were then continuously stirred in an ice bath at $-7^{\circ} \mathrm{C}$, while ethanol was added dropwise, at a flow rate of $1 \mathrm{~mL} /$ min, until the desired concentration was reached. The tubes were then incubated at $15^{\circ} \mathrm{C}$ for $3 \mathrm{~h}$, followed by centrifugation at $12,900 \mathrm{~g}$ for $10 \mathrm{~min}$. The precipitate was suspended in $5.0 \mathrm{~mL}$ of $0.2 \mathrm{~mol} / \mathrm{L}$ sodium citrate buffer ( $\mathrm{pH} \mathrm{5.0)}$ for the quantification of total protein and xylanase activity. All the experiments were carried out in triplicate, and the data were calculated as means \pm standard deviations.

\section{Kinetics of xylanase precipitation with ethanol}

For the kinetic study of xylanase precipitation with ethanol under the selected process conditions, the $\mathrm{pH}$ values of the crude SSF and SmF enzyme preparations were adjusted to $\mathrm{pH} 5.5$ (as described before) and 1.0 $\mathrm{mL}$ volumes were transferred to $15 \mathrm{~mL}$ Falcon tubes. The tubes were kept under stirring in an ice bath at $-7.0{ }^{\circ} \mathrm{C}$ and ethanol was added dropwise until reaching a concentration of $85 \%(\mathrm{v} / \mathrm{v})$. The tubes were then incubated at $15{ }^{\circ} \mathrm{C}$, withdrawn at different times, and centrifuged at $12,900 \mathrm{~g}$ for $10 \mathrm{~min}$. The precipitates were dissolved in $5.0 \mathrm{~mL}$ of $0.2 \mathrm{~mol} / \mathrm{L}$ sodium citrate buffer ( $\mathrm{pH}$ 5.0) for the quantification of total protein and xylanase activity. All the experiments were carried out in triplicate, and the data were calculated as means \pm standard deviations.

\section{Enzyme activity assay}

The xylanase activity was measured according to the methodology described by Bailey and Poutanen (Bailey and Poutanen, 1989), with incubation of 1.0 $\mathrm{mL}$ of the suitably diluted samples at $50{ }^{\circ} \mathrm{C}$ for 30 min with a substrate of $1 \%$ beechwood xylan (Sigma, USA) solution prepared in $0.20 \mathrm{~mol} / \mathrm{L}$ sodium acetate buffer ( $\mathrm{pH}$ 5.0). Here, one unit of xylanase activity corresponds to $1 \mu \mathrm{mol}$ of xylose released per minute at $\mathrm{pH} 5.0$ and $50{ }^{\circ} \mathrm{C}$. Quantification of the reducing groups was performed according to the dinitrosalicylic acid (DNS) method (Miller, 1959).

\section{Total protein}

The total protein concentrations in the enzymatic samples were determined by the Bradford method (Bradford, 1976), using bovine serum albumin as a standard.

\section{RESULTS AND DISCUSSION}

\section{Thermal and pH stability of xylanase}

A preliminary set of experiments was carried out to evaluate the thermal and $\mathrm{pH}$ stability of the xylanase present in the crude enzymatic preparations obtained by cultivation of $A$. niger under SSF and SmF. These analyses were required in order to establish the ranges of $\mathrm{pH}$ and temperature that would be appropriate in the subsequent precipitation studies. The xylanase stability results are presented in terms of the linear fitting parameters obtained by plotting the residual activity as a function of incubation time of the crude enzyme preparations at different temperatures and $\mathrm{pH}$.

In the case of thermal stability (Table 1), no significant changes in xylanase activity or protein concentration were detected up to $180 \mathrm{~min}$ of incubation at 15,30 , or $45^{\circ} \mathrm{C}$, for both SSF and SmF enzyme preparations, as shown by the very low angular coefficient values obtained for all the temperatures tested. These results indicated that the xylanases produced by $A$. niger presented good thermal stability (for the temperatures and time periods tested). In addition, it is noteworthy that no difference was observed between the thermal stabilities of the xylanases obtained from the different cultivation systems.

These findings are in agreement with literature reports on the thermal stability of xylanases from different Aspergillus strains. For instance, Guimarães et al. (2013) found that the xylanase produced by $A$. niger under $\mathrm{SmF}$ retained over $85 \%$ activity after $2 \mathrm{~h}$ of incubation at $50{ }^{\circ} \mathrm{C}$. Xylanase produced by $A$. terreus under $\mathrm{SmF}$ showed no significant decrease in activity during $3 \mathrm{~h}$ incubation at 30 and $45{ }^{\circ} \mathrm{C}$ (Bakri et al., 2010). Similar thermal stability has also been reported for xylanases produced under SSF by $A$. niger, $A$. ochraceus, and $A$. niveus, which remained stable for up to $1 \mathrm{~h}$ at $50{ }^{\circ} \mathrm{C}$ (Betini et al., 2009).

Table 2 presents the $\mathrm{pH}$ stability results obtained for incubation of the SSF and SmF enzyme preparations at different $\mathrm{pH}$. Similar to the previous results for thermal stability, no significant changes were observed 
Table 1. Thermal stability study of xylanase enzymes produced by $A$. niger under SSF and SmF: parameters of the linear fits for residual enzyme activity $\left(\right.$ Ativ $\left.\left.\right|_{t}\right)$ or protein concentration $\left(\left.\operatorname{Prot}\right|_{t}\right)$, as a function of time.

\begin{tabular}{|c|c|c|c|c|c|c|c|}
\hline & \multirow{2}{*}{$\begin{array}{l}\text { Temperature } \\
\left({ }^{\circ} \mathrm{C}\right)\end{array}$} & \multicolumn{3}{|c|}{ Xylanase activity(IU/mL) } & \multicolumn{3}{|c|}{ Protein concentration $(\mathrm{mg} / \mathrm{mL})$} \\
\hline & & Activ $\left.\right|_{0}$ & $\mathbf{a}_{\text {activ }}\left(10^{-3}\right)$ & $\mathbf{R}^{2}$ & $\left.\operatorname{Prot}\right|_{0}$ & $\mathbf{a}_{\text {prot }}\left(10^{-5}\right)$ & $\mathbf{R}^{2}$ \\
\hline \multirow{3}{*}{ SSF } & 15 & 6.50 & 2.6 & 0.970 & 0.23 & 1.0 & 0.983 \\
\hline & 30 & 6.84 & 2.1 & 0.975 & 0.22 & 20.0 & 0.880 \\
\hline & 45 & 6.90 & -1.1 & 0.984 & 0.22 & 2.0 & 0.964 \\
\hline \multirow{3}{*}{ SmF } & 15 & 6.22 & -1.2 & 0.980 & 0.07 & -4.0 & 0.957 \\
\hline & 30 & 6.34 & -1.1 & 0.983 & 0.05 & 8.0 & 0.931 \\
\hline & 45 & 6.39 & 1.3 & 0.977 & 0.05 & 10.0 & 0.906 \\
\hline
\end{tabular}

Values from linear fitting of the plots of protein concentration or xylanase activity, as a function of time. Ativ $\left.\right|_{\mathrm{t}}=$ Ativ $\left.\right|_{0}+\mathrm{a}_{\mathrm{ativ}} \mathrm{t}$ and Prot $\left.\right|_{\mathrm{t}}=$ Prot $\left.\right|_{0}+$ $\mathrm{a}_{\text {prot }} \mathrm{t}$. Ativ $\left.\right|_{0}$ and Prot $\left.\right|_{0}$, linear coefficients; $\mathrm{a}_{\text {ativ }} \mathrm{t}$ and $\mathrm{a}_{\text {prot }} \mathrm{t}$, angular coefficients; $\mathrm{R}^{2}$, correlation coefficient.

in xylanase activity or protein concentration after incubation of the crude enzyme preparations for 180 $\min$ at $30^{\circ} \mathrm{C}$, using $\mathrm{pH}$ ranging from 3.0 to 8.0 . It is interesting to note that for $\mathrm{pH}$ 6.0, similar stability results were obtained using two different buffers, indicating that the nature of the salts present in the buffers did not affect the analysis.

The results corroborated the findings of other studies concerning the $\mathrm{pH}$ stability of xylanase from Aspergillus. Guimarães et al. (2013) found that $A$. niger xylanase retained over $95 \%$ of the initial activity after incubation at $\mathrm{pH}$ in the range from 3.0 to 8.0 for up to $1 \mathrm{~h}$. Xylanases from $A$. ochraceus and $A$. terricola presented stability greater than $70 \%$ when incubated in the $\mathrm{pH}$ range from 2.5 to 8.0 for up to $1 \mathrm{~h}$
(Michelin et al., 2010). Xylanase from A. niger was stable at $\mathrm{pH}$ in the range from 2.0 to 7.0 , retaining over $75 \%$ activity after $1 \mathrm{~h}$, while xylanases of $A$. ochraceus and $A$. niveus were stable at $\mathrm{pH}$ from 3.0 to 7.0 , with more than $70 \%$ activity retained (Betini et al., 2009).

In light of all the previous results concerning the thermal and $\mathrm{pH}$ stability of $A$. niger xylanase from both SSF and SmF cultivation systems, temperatures between 15 and $45{ }^{\circ} \mathrm{C}$ and $\mathrm{pH}$ values in the range from 3.0 to 8.0 were selected for evaluation of ethanol precipitation. The xylanases were quite stable over these ranges of temperature and $\mathrm{pH}$, within the period studied (up to $3 \mathrm{~h}$ ). This information is important in order to avoid any misinterpretation of the following ethanol precipitation results.

Table 2. Stability, at different $\mathrm{pH}$, of xylanase enzymes produced by A. niger under SSF and SmF: parameters of the linear fits for residual enzyme activity or protein concentration, as a function of time.

\begin{tabular}{|c|c|c|c|c|c|c|c|}
\hline & \multirow{2}{*}{$\mathrm{pH}$} & \multicolumn{3}{|c|}{ Xylanase activity (IU/mL) } & \multicolumn{3}{|c|}{ Protein concentration $(\mathrm{mg} / \mathrm{mL})$} \\
\hline & & Activ $\left.\right|_{0}$ & $\mathbf{a}_{\text {activ }}\left(10^{-3}\right)$ & $\mathbf{R}^{2}$ & Prot $\left.\right|_{0}$ & $\mathbf{a}_{\text {prot }}\left(10^{-5}\right)$ & $\mathbf{R}^{2}$ \\
\hline \multirow{7}{*}{ SSF } & $3.0^{\mathrm{a}}$ & 8.78 & 3.6 & 0.911 & 0.16 & 9.0 & 0.790 \\
\hline & $4.0^{\mathrm{a}}$ & 9.09 & -4.2 & 0.821 & 0.21 & -2.0 & 0.964 \\
\hline & $5.0^{\mathrm{a}}$ & 7.61 & 4.6 & 0.917 & 0.24 & -20.0 & 0.931 \\
\hline & $6.0^{\mathrm{a}}$ & 8.59 & 5.8 & 0.950 & 0.24 & -10.0 & 0.918 \\
\hline & $6.0^{\mathrm{b}}$ & 9.65 & 0.8 & 0.972 & 0.25 & -5.0 & 0.988 \\
\hline & $7.0^{\mathrm{b}}$ & 9.32 & -3.3 & 0.967 & 0.25 & -10.0 & 0.945 \\
\hline & $8.0^{\mathrm{b}}$ & 8.94 & -1.0 & 0.909 & 0.26 & -4.0 & 0.930 \\
\hline \multirow{7}{*}{ SmF } & $3.0^{\mathrm{a}}$ & 7.67 & -0.6 & 0.861 & 0.06 & 0.7 & 0.931 \\
\hline & $4.0^{\mathrm{a}}$ & 8.96 & -4.6 & 0.841 & 0.07 & 3.0 & 0.890 \\
\hline & $5.0^{\mathrm{a}}$ & 6.93 & 8.3 & 0.971 & 0.08 & -9.0 & 0.897 \\
\hline & $6.0^{\mathrm{a}}$ & 8.72 & 6.6 & 0.898 & 0.08 & -6.0 & 0.949 \\
\hline & $6.0^{\mathrm{b}}$ & 8.58 & 0.8 & 0.895 & 0.08 & 1.0 & 0.970 \\
\hline & $7.0^{\mathrm{b}}$ & 8.67 & -1.7 & 0.967 & 0.09 & -3.0 & 0.937 \\
\hline & $8.0^{\mathrm{b}}$ & 8.17 & -2.7 & 0.926 & 0.10 & -5.0 & 0.929 \\
\hline
\end{tabular}

Values from linear fitting of the plots of protein concentration or xylanase activity, as a function of time. Ativ $\left.\right|_{t}=\left.\operatorname{Ativ}\right|_{0}+a_{\text {ativ }} t$ and Prot $\left.\right|_{t}=\left.\operatorname{Prot}\right|_{0}+a_{\text {prot }} t$. Ativ $\left.\right|_{0}$ and Prot $\left.\right|_{0}$, linear coefficients; $\mathrm{a}_{\text {ativ }} \mathrm{t}$ and $\mathrm{a}_{\text {prot }} \mathrm{t}$, angular coefficients; $\mathrm{R}^{2}$, correlation coefficient.

${ }^{\text {a} B u f f e r: ~} 0.2 \mathrm{~mol} / \mathrm{L}$ sodium citrate.

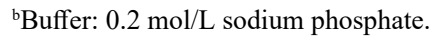




\section{Determination of the cloud point}

The proteins from SSF and SmF showed slightly different behaviors in terms of the minimum concentration of ethanol required for detection of a visible haze in the medium (the cloud point). The crude enzyme preparation from SSF required 50.8\% $(\mathrm{v} / \mathrm{v})$ of ethanol to reach the cloud point, while the SmF preparation required an average of $56.2 \%(\mathrm{v} / \mathrm{v})$ of ethanol. This could have been due to the higher concentration of proteins in the SSF medium $(0.24$ $\mathrm{mg} / \mathrm{mL})$, compared to the $\mathrm{SmF}$ medium $(0.11 \mathrm{mg} / \mathrm{mL})$, which enabled supersaturation to be achieved at a lower ethanol concentration. A higher initial concentration of proteins in the medium leads to higher supersaturation, at a given concentration of ethanol, which in turn leads to increased protein precipitation (Nakadai and Nasuno, 1989). Therefore, it was important to know the cloud point in order to determine the minimum concentration of ethanol required in the subsequent precipitation studies.

\section{Ethanol precipitation of xylanases}

An overall analysis of the results of xylanase precipitation using ethanol, performed according to the $2^{2}$ central composite design, showed that protein recoveries in the precipitates from SSF were mostly higher than in those from SmF (Table 3). This could have been due to the 2.4-fold higher initial concentration of proteins in the SSF medium, compared to the SmF medium. The same rationale could be extended to the xylanase activity, since the highest recoveries were obtained from the $\mathrm{SmF}$ medium, with initial activity values of 7.09 and $5.16 \mathrm{IU} / \mathrm{mL}$ for $\mathrm{SmF}$ and $\mathrm{SSF}$, respectively. The crude enzyme preparations from SSF and SmF also presented different initial xylanase specific activities $(17.79 \mathrm{IU} / \mathrm{mg}$ for SSF and 59.08 $\mathrm{IU} / \mathrm{mg}$ for $\mathrm{SmF}$ ), as well as different final xylanase specific activities in the precipitates, hence resulting in different purification factors.

For the precipitation with ethanol using the SSF medium, the highest recoveries of protein (between 78.9 and $86.2 \%$ ) and xylanase activity (between 59.8 and $64.4 \%$ ) were obtained in test runs $7-11$, in which the initial $\mathrm{pH}$ was 5.5 , irrespective of the concentration of ethanol used (Table 3). In the case of the precipitations carried out with the SmF broth, adjustment of the $\mathrm{pH}$ to 5.5 and increasing the ethanol concentration from 78 to $92 \%(\mathrm{v} / \mathrm{v})$ resulted in $22 \%$ and $16 \%$ increases in the recoveries of protein and xylanase activity, respectively.

Pareto chart analysis was used to determine the degree of significance of the effect of each variable on the recoveries of xylanase activity and protein, for SSF (Figure 1) and SmF (Figure 2). For SSF, only the effect of $\mathrm{pH}$ was statistically significant $(\mathrm{p}<0.05)$ for the recoveries of both xylanase activity (Figure 1A) and protein (Figure 1B). For xylanase recovery from precipitation using the $\mathrm{SmF}$ broth, only the quadratic $\mathrm{pH}$ effect was significant, within the range evaluated (Figure 2A). For protein recovery from $\mathrm{SmF}$ (Figure 2B), the quadratic $\mathrm{pH}$ effect and the linear ethanol concentration effect were both significant at the $95 \%$ confidence level $(\mathrm{p}<0.05)$. This quadratic effect - that leads to a $\mathrm{pH}$ of maximun recovery for a fixed ethanol concentration - is due to the charge of the

Table 3. Matrix of coded and real values of the central composite design (CCD) and responses for ethanol precipitation of the xylanase enzymes produced by $A$. niger under SSF and SmF.

\begin{tabular}{|c|c|c|c|c|c|c|c|c|c|c|}
\hline \multirow[b]{2}{*}{ Run } & \multirow[b]{2}{*}{$\mathrm{pH}$} & \multirow{2}{*}{$\begin{array}{c}\text { Ethanol } \\
(\%)\end{array}$} & \multicolumn{4}{|c|}{ SSF } & \multicolumn{4}{|c|}{$\mathrm{SmF}$} \\
\hline & & & $\mathrm{X}_{\mathrm{r}}(\%)$ & $\mathrm{P}_{\mathrm{r}}(\%)$ & $\begin{array}{c}\mathrm{A}_{\mathrm{e}}(\mathrm{IU} / \\
\mathrm{mg})\end{array}$ & $\mathrm{P}_{\mathrm{F}}$ & $\mathrm{X}_{\mathrm{r}}(\%)$ & $\mathrm{P}_{\mathrm{r}}(\%)$ & $\begin{array}{c}\mathrm{A}_{\mathrm{e}}(\mathrm{IU} / \\
\mathrm{mg})\end{array}$ & $\mathrm{P}_{\mathrm{F}}$ \\
\hline 1 & $-1(4.0)$ & $-1(80)$ & 42.6 & 59.4 & 14.9 & 0.83 & 54.2 & 54.6 & 27.3 & 0.46 \\
\hline 2 & $-1(4.0)$ & $1(90)$ & 45.1 & 63.0 & 14.8 & 0.83 & 54.6 & 68.3 & 53.4 & 0.90 \\
\hline 3 & $1(7.0)$ & $-1(80)$ & 56.1 & 83.0 & 14.0 & 0.78 & 65.4 & 61.0 & 51.1 & 0.86 \\
\hline 4 & $1(7.0)$ & $1(90)$ & 55.1 & 76.4 & 15.0 & 0.84 & 55.9 & 76.5 & 48.9 & 0.83 \\
\hline 5 & $-1.41(3.4)$ & $0(85)$ & 48.6 & 45.1 & 22.4 & 1.25 & 58.3 & 46.3 & 40.7 & 0.69 \\
\hline 6 & 1.41(7.6) & $0(85)$ & 46.6 & 69.8 & 13.8 & 0.77 & 51.9 & 51.1 & 60.0 & 1.02 \\
\hline 7 & $0(5.5)$ & $-1.41(78)$ & 60.0 & 78.9 & 15.8 & 0.88 & 57.8 & 63.3 & 60.3 & 1.02 \\
\hline 8 & $0(5.5)$ & $1.41(92)$ & 59.8 & 85.6 & 14.5 & 0.81 & 73.5 & 85.3 & 46.0 & 0.78 \\
\hline 9 & $0(5.5)$ & $0(85)$ & 62.1 & 81.4 & 15.8 & 0.88 & 65.8 & 72.1 & 48.7 & 0.82 \\
\hline 10 & $0(5.5)$ & $0(85)$ & 64.4 & 86.2 & 14.9 & 0.83 & 68.7 & 76.9 & 47.7 & 0.80 \\
\hline 11 & $0(5.5)$ & $0(85)$ & 61.8 & 82.7 & 15.6 & 0.87 & 66.4 & 73.4 & 48.3 & 0.82 \\
\hline
\end{tabular}

$\mathrm{X}_{\mathrm{r}}$, xylanase activity recovered; $\mathrm{P}_{\mathrm{r}}$, recovered protein concentration; $\mathrm{A}_{\mathrm{e}}$, specific xylanase activity in the precipitate; $\mathrm{P}_{\mathrm{F}}$, purification factor. SSF reference values: initial xylanase activity, $5.16 \mathrm{IU} / \mathrm{mL}$; initial protein concentration, $0.29 \mathrm{mg} / \mathrm{mL}$; specific activity of the initial xylanase, $17.79 \mathrm{IU} / \mathrm{mg}$. SmF reference values: initial xylanase activity, $7.09 \mathrm{IU} / \mathrm{mL}$; initial protein concentration, $0.12 \mathrm{mg} / \mathrm{mL}$; specific activity of the initial xylanase, $59.08 \mathrm{IU} / \mathrm{mg}$. 
molecules. Most of proteins have their $\mathrm{pI}$ in the range of neutrality to slightly acidic $\mathrm{pH}$. Values of $\mathrm{pH}$ distant from this range lead to charged molecules that tend to repel each other.

Table 4 provides the coefficients of the mathematical model and the statistical parameters obtained by analysis of the CCD responses for the xylanase activity and protein recoveries after ethanol precipitation of the SSF and SmF crude preparations. The low value for the coefficient of determination (R) for acitivity recovery may be explained by the fact that A. niger xylanases precipitated are not a single type of molecule, but xylanases with different molecular masses and $\mathrm{pI}$ values.

In general, the $\mathrm{pH}$ effect was greater than the ethanol concentration effect, as can be seen from the coefficient values listed in Table 4. The ANOVA correlation coefficient and F-test values indicated satisfactory prediction by the models used to describe the response surface plots of the xylanase activity and protein recoveries for SSF (Figure 3) and SmF (Figure 4). The response surface plots showed that, in the case of ethanol precipitation of the enzyme complex produced by SSF, higher xylanase activity and total protein recoveries were obtained for an initial extract $\mathrm{pH}$ in the range from 5.5 to 7.0. Under these conditions, there was no significant influence of the ethanol concentration (Figure 3). For the ethanol precipitation using the $\mathrm{SmF}$ broth extract, the results showed that, for both xylanase activity and total protein, the best recovery was obtained when the $\mathrm{pH}$ was adjusted to the center point value, 5.5 (Figure 4). However, unlike the precipitation using the SSF extract, the concentration of the precipitant affected the precipitation process of the $\mathrm{SmF}$ broth extract, at any $\mathrm{pH}$, with the effect being greater at lower $\mathrm{pH}$.
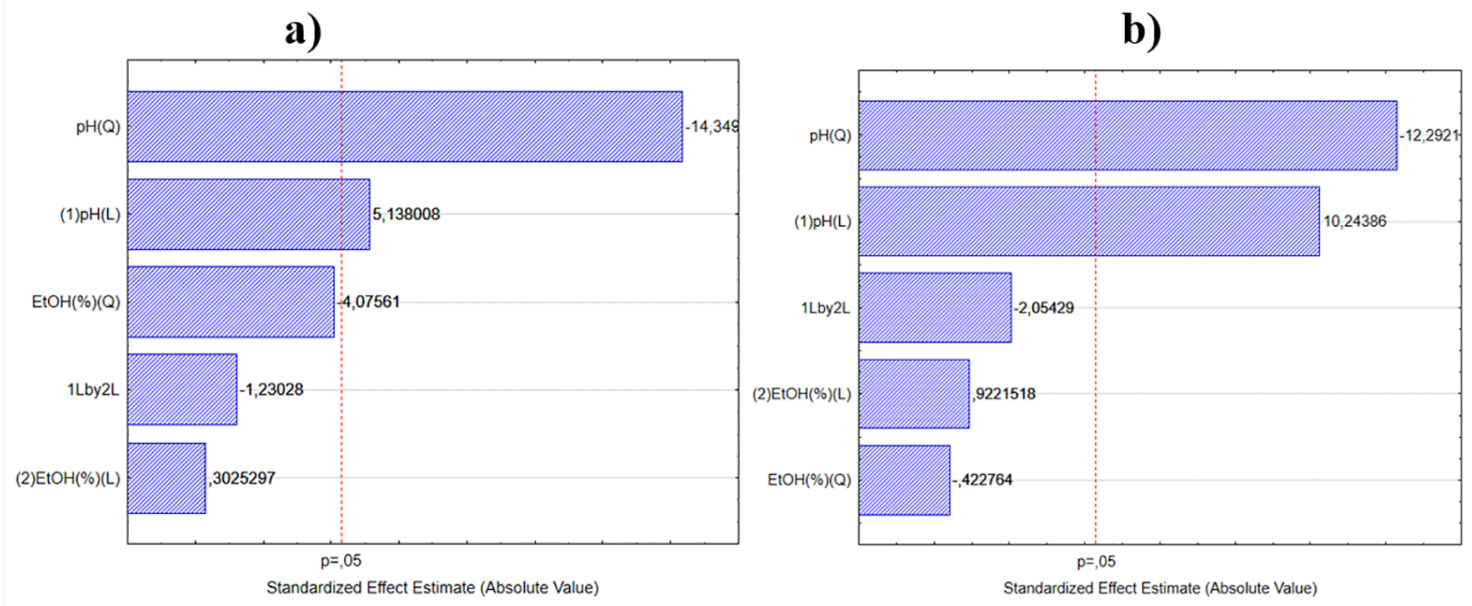

Figure 1. Pareto chart for the effects of the variables ethanol concentration and $\mathrm{pH}$ on the recovery of xylanase activity (A) and total protein (B) for the enzymatic complex from A. niger cultivated under SSF.

a)

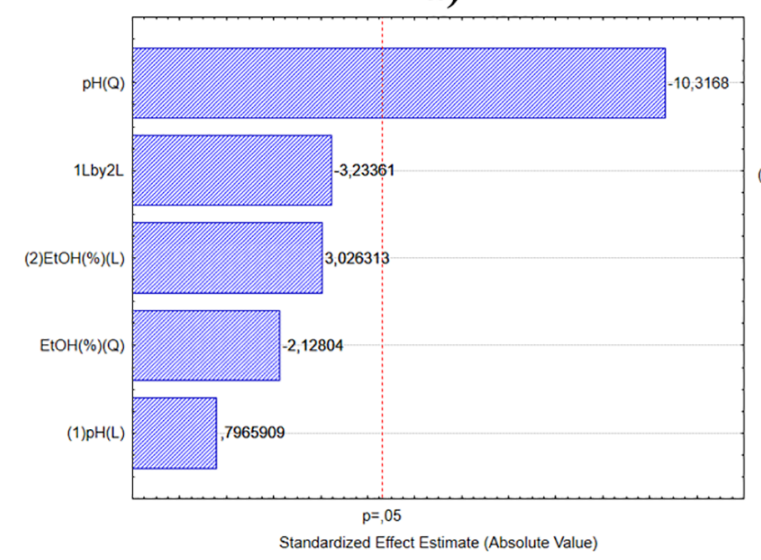

b)

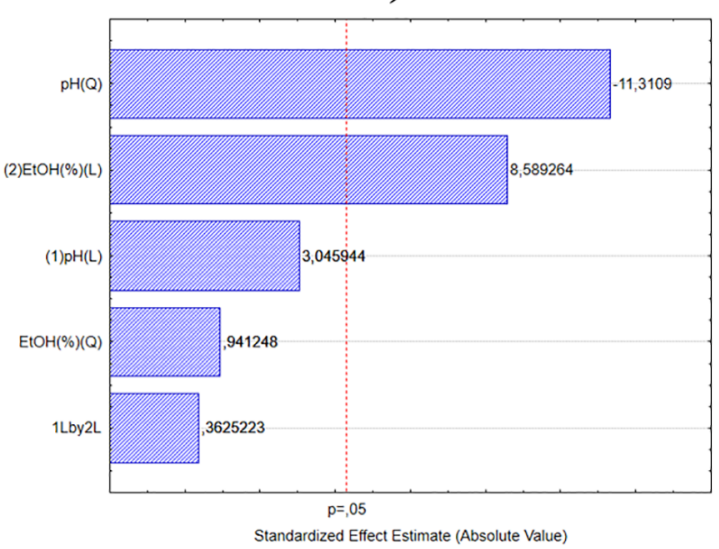

Figure 2. Pareto chart for the effects of the variables ethanol concentration and $\mathrm{pH}$ on the recovery of xylanase activity (A) and total protein (B) for the enzymatic complex from A. niger cultivated under SmF. 
Table 4. Coefficient values and statistical analysis for total protein concentration and xylanase activity.

\begin{tabular}{|c|c|c|c|c|c|c|c|c|}
\hline & \multicolumn{4}{|c|}{$\mathrm{SSF}$} & \multicolumn{4}{|c|}{$\mathrm{SmF}$} \\
\hline & \multicolumn{2}{|c|}{$\begin{array}{c}\text { Total protein } \\
\text { concentration }\end{array}$} & \multicolumn{2}{|c|}{ Xylanase activity } & \multicolumn{2}{|c|}{$\begin{array}{c}\text { Total protein } \\
\text { concentration }\end{array}$} & \multicolumn{2}{|c|}{ Xylanase activity } \\
\hline & Coefficient & p-value & Coefficient & p-value & Coefficient & p-value & Coefficient & $\mathrm{p}$-value \\
\hline Mean & $83.43^{*}$ & 0.000 & $66.30^{*}$ & 0.000 & $74.13^{*}$ & 0.000 & $66.97^{*}$ & 0.000 \\
\hline $\mathrm{pH}$ & $8.99^{*}$ & 0.009 & $2.58^{*}$ & 0.036 & 2.67 & 0.093 & 0.43 & 0.509 \\
\hline $\mathrm{pH}^{2}$ & $-12.84^{*}$ & 0.007 & $-8.59^{*}$ & 0.005 & $-11.82^{*}$ & 0.008 & $-6.65^{*}$ & 0.009 \\
\hline $\mathrm{EtOH}$ & 0.81 & 0.454 & 0.15 & 0.791 & $7.54^{*}$ & 0.013 & 1.64 & 0.094 \\
\hline $\mathrm{EtOH}^{2}$ & -0.44 & 0.714 & -2.44 & 0.055 & 0.98 & 0.446 & -1.37 & 0.167 \\
\hline $\mathrm{pHxEtOH}$ & -2.55 & 0.176 & -0.88 & 0.344 & 0.45 & 0.752 & -2.48 & 0.084 \\
\hline $\mathrm{R}$ & 0.98 & & 0.79 & & 0.98 & & 0.60 & \\
\hline F-value & 50.77 & & 3.83 & & 30.72 & & 1.48 & \\
\hline
\end{tabular}

R: coefficient of determination; ${ }^{*}$ Significant at $\mathrm{p}<0.05$.

Overall, the values for the conditions at the central point $(85 \%(\mathrm{v} / \mathrm{v})$ ethanol; $\mathrm{pH} 5.5)$ resulted in the best recoveries of xylanase from both the SSF and the $\mathrm{SmF}$ preparations, with average values of $63 \%$ and $67 \%$, respectively. These precipitation conditions were therefore selected in the subsequent kinetic study. The recoveries were superior to those previously reported in studies of xylanase precipitation. For instance, Farinas et al. (2011) reported that the use of $80 \%$ (v/v) ethanol to precipitate xylanases from A. niger cultivated under SSF resulted in up to $23 \%$ recovery. This difference could have been due to the different precipitation operational conditions employed, especially the temperature, which must be controlled in order to avoid protein refolding and denaturation.

\section{Kinetic study of xylanase precipitation with ethanol}

The kinetic curves for xylanase precipitation with ethanol using the SSF and SmF crude enzyme preparations ( $\mathrm{pH}$ 5.5) are shown in Figures $5 \mathrm{~A}$ and $\mathrm{B}$, respectively. These correspond to the temporal profiles for the xylanase activity and protein concentration recoveries obtained using precipitation at $15{ }^{\circ} \mathrm{C}$ with $85 \%(\mathrm{v} / \mathrm{v})$ of ethanol. The recovery of total protein from the SSF medium showed a rapid initial increase, reaching $90 \%$ after $75 \mathrm{~min}$, and then remained stable. The recovery of xylanase activity from the SSF medium also remained stable (at around 60\%) from the start of the period up to $360 \mathrm{~min}$, after which there was a slight decrease (Figure 5A). The decrease could have been due to enzyme denaturation following exposure to a high concentration of ethanol for such a long period. For the precipitation of proteins from the SmF broth (Figure 5B), the recovery of total protein increased in a)

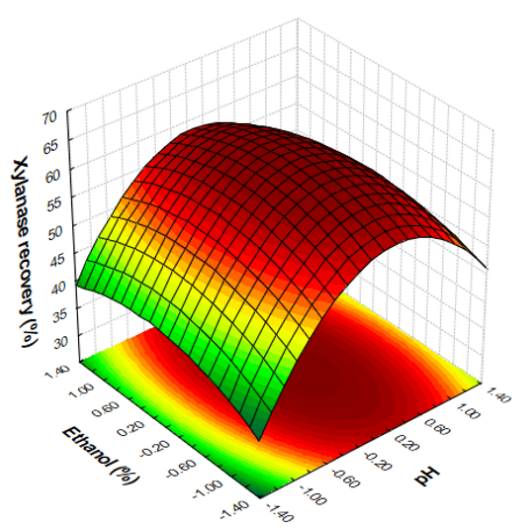

b)

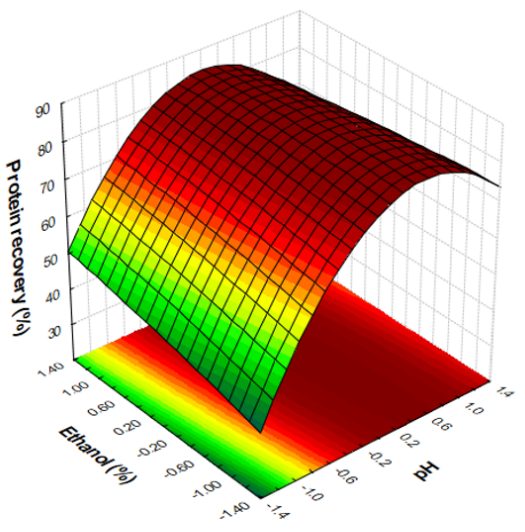

Figure 3. Response surface plots for ethanol precipitation of the enzymatic complex from $A$. niger cultivated under SSF, varying the ethanol concentration and $\mathrm{pH}$ values. Recovery of xylanase activity (A) and total protein (B). 
a)

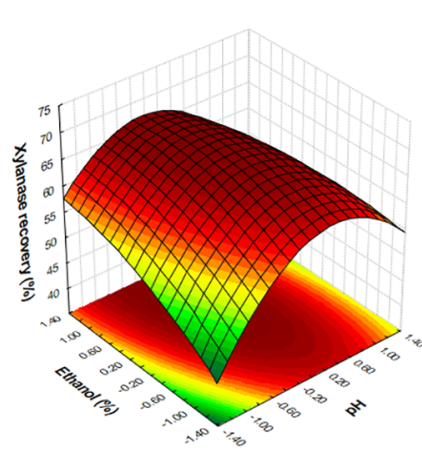

b)

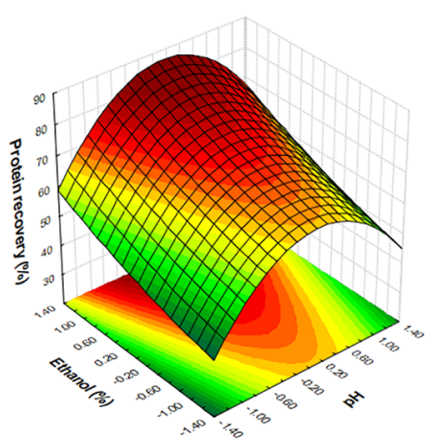

the first $45 \mathrm{~min}$ and then remained quite stable. For the $\mathrm{SmF}$ broth, the xylanase activity recovery was stable (at around $80 \%$ ) from the beginning of the period up to 360 $\min$.

The differences in the initial total protein concentrations and xylanase activities of the crude enzyme preparations obtained from SSF and SmF were reflected in the specific activity values and, consequently, in the purification factors achieved after precipitation. For example, the maximum purification factors obtained for SSF and SmF were 0.88 and 1.12, respectively. For both SSF and SmF, the highest purification factor values were found using short precipitation periods, when much of the total protein was still in the soluble phase. These results showed that relatively short periods of time (up to 15 min) were sufficient to recover most of the xylanase activity precipitated under the operational conditions employed $\left(15^{\circ} \mathrm{C} ; \mathrm{pH} 5.5 ; 85 \%\right.$ (v/v) ethanol). Overall, the results achieved here for xylanase precipitation with ethanol were very satisfactory, when compared to the literature (Table 5), indicating that the procedure can be considered as a potential DSP unit operation for the concentration of $A$. niger xylanases from different cultivation systems.

Figure 4. Response surface plots for ethanol precipitation of the enzymatic complex from $A$. niger cultivated under $\mathrm{SmF}$, varying the ethanol concentration and $\mathrm{pH}$ values. Recovery of xylanase activity (A) and total protein (B).

a)

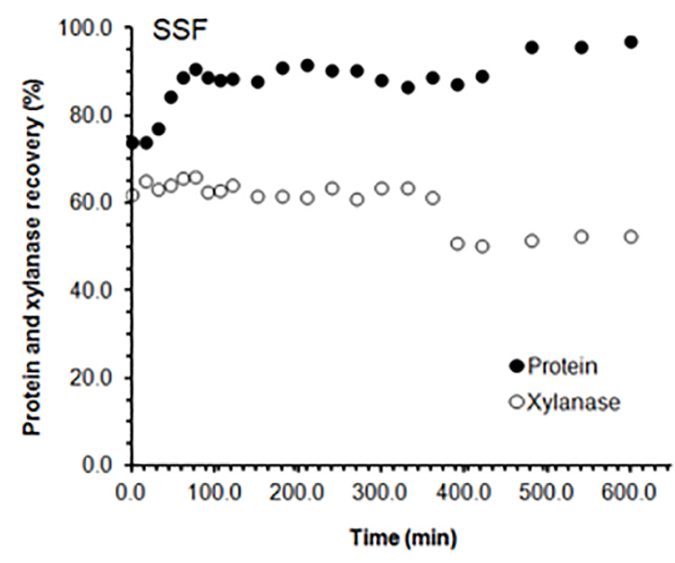

b)

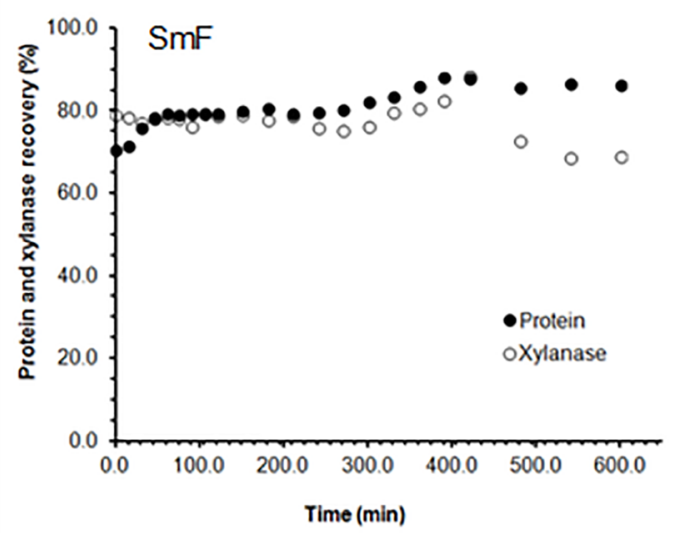

Figure 5. Kinetics of ethanol precipitation of the crude enzymatic SSF extract (a) and SmF broth (b) from A. niger. Initial xylanase activities: $4.15 \mathrm{IU} / \mathrm{mL}$ (a) and $7.68 \mathrm{UI} / \mathrm{mL}$ (b); initial protein concentrations: $0.23 \mathrm{mg} / \mathrm{mL}$ (a) and $0.12 \mathrm{mg} / \mathrm{mL}$ (b). Precipitation conditions: $15^{\circ} \mathrm{C}, \mathrm{pH} 5.5,85 \%(\mathrm{v} / \mathrm{v})$ ethanol. 
Table 5. Comparative data from ethanol precipitation studies of xylanase enzymes produced by different fungal strains cultivated under SSF and SmF.

\begin{tabular}{|c|c|c|c|c|c|c|}
\hline Cultivation System & Microorganism & Precipitant (v/v) & Time (min) & $X_{R}(\%)$ & $\mathrm{P}_{\mathrm{F}}$ & Reference \\
\hline \multirow{4}{*}{ SSF } & A. niger & $85 \%$ ethanol & 15 & 65.0 & 0.74 & This work \\
\hline & A. niger & $80 \%$ ethanol & 180 & 23.0 & - & (Farinas et al., 2011) \\
\hline & & $80 \%$ ammonium sulfate & & 27.0 & - & \\
\hline & T. harzianum & $80 \%$ ethanol & 30 & 94.0 & - & (Fadel, 2001) \\
\hline \multirow{4}{*}{$\mathrm{SmF}$} & A. niger & $85 \%$ ethanol & 15 & 79.0 & 1.03 & This work \\
\hline & T. harzianum & $90 \%$ ethanol & 0 & 100.0 & - & (Marino et al., 2015) \\
\hline & Chainia sp. & $66 \%$ ethanol & overnight & 78.5 & 13.70 & (Varma et al., 1999) \\
\hline & & $80 \%$ ethanol & & 99.0 & 15.97 & \\
\hline
\end{tabular}

$\mathrm{X}_{\mathrm{R}}$ : xylanase activity recovered; $\mathrm{P}_{\mathrm{F}}$ : purification factor.

\section{CONCLUSIONS}

A systematic comparative study was undertaken of the ethanol precipitation of xylanases produced by A. niger cultivated under SSF and SmF. The process was evaluated using a central composite design, considering the effects of $\mathrm{pH}$ and ethanol concentration on recovery yields. There was a significant effect of $\mathrm{pH}$ on the total protein and xylanase activity recoveries, with the best results for an initial $\mathrm{pH}$ of 5.5. The ethanol concentration had no significant effect on the precipitation of xylanase from the SSF extract, within the range tested, but had a more pronounced effect in the case of the $\mathrm{SmF}$ extract, especially at acidic $\mathrm{pH}$. The kinetic profiles showed that relatively short periods of time $(15 \mathrm{~min})$ were sufficient to recover most of the xylanase activity precipitated under the conditions employed, reaching xylanase recoveries of $65 \%$ and $79 \%$ for the SSF and SmF enzymatic complexes, respectively. In summary, our findings demonstrate that ethanol precipitation is a potential DSP unit operation for the concentration of xylanases from different cultivation systems.

\section{ACKNOWLEDGMENTS}

The authors thank the Brazilian institutions CAPES, FAPESP, CNPq, and EMBRAPA for financial support.

\section{REFERENCES}

Ahmad, Z., Butt, M.S., and Riaz M., Partial purification and characterization of xylanase produced from Aspergillus niger using wheat bran. Pakistan Journal of Agricultural Sciences, Faisalabad, 50(3) 433-437 (2013).

Bailey, M.J. and Poutanen, K., Production of xylanolytic enzymes by strains of Aspergillus. Applied Microbiology and Biotechnology, 30(1) 5-10 (1989).
Bakri, Y., Masson, M. and Thonart, P., Isolation and Identification of Two New Fungal Strains for Xylanase Production. Applied Biochemistry and Biotechnology, 162(6) 1626-1634 (2010).

Betini, J.H.A., Michelin, M., Peixoto-Nogueira, S.C., Jorge, J.A., Terenzi, H.F. and Polizeli, M., Xylanases from Aspergillus niger, Aspergillus niveus and Aspergillus ochraceus produced under solid-state fermentation and their application in cellulose pulp bleaching. Bioprocess and Biosystems Engineering, 32(6) 819-824 (2009).

Bokhari, S.A.I., Latif, F. and Rajoka, M.I., Purification and characterization of xylanases from Thermomyces lanuginosus and its mutant derivative possessing novel kinetic and thermodynamic properties. World Journal of Microbiology \& Biotechnology, 25(3) 493-502 (2009).

Bradford, M.M., Rapid and sensitive method for quantitation of microgram quantities of protein utilizing principle of protein-dye binding. Analytical Biochemistry, 72(1-2), 248-254 (1976).

Chanwicha, N., Katekaew, S., Aimi, T. and Boonlue, S., Purification and characterization of alkaline xylanase from Thermoascus aurantiacus var. levisporus KKU-PN-I2-1 cultivated by solid-state fermentation. Mycoscience, 56(3) 309-318 (2015).

Chapla, D., Divecha, J., Madamwar, D. and Shah, A., Utilization of agro-industrial waste for xylanase production by Aspergillus foetidus MTCC 4898 under solid state fermentation and its application in saccharification. Biochemical Engineering Journal, 49(3) 361-369 (2010).

Chipeta, Z.A., du Preez, J.C. and Christopher, L., Effect of cultivation $\mathrm{pH}$ and agitation rate on growth and xylanase production by Aspergillus oryzae in spent sulphite liquor. Journal of Industrial Microbiology \& Biotechnology, 35(6) 587-594 (2008). 
Collins, T., Gerday, C. and Feller, G., Xylanases, xylanase families and extremophilic xylanases. Fems Microbiology Reviews, 29(3) 3-23 (2005).

Couri, S. and deFarias, A.X., Genetic manipulation of Aspergillus niger for increased synthesis of pectinolytic enzymes. Revista De Microbiologia, 26(4) 314-317 (1995).

de Vries, R.P., Regulation of Aspergillus genes encoding plant cell wall polysaccharide-degrading enzymes; relevance for industrial production. Applied Microbiology and Biotechnology , 61(1) 10-20 (2003).

Dodd, D. and Cann, I., Enzymatic deconstruction of xylan for biofuel production. Global Change Biology Bioenergy, 1(1) 2-17 (2009).

Fadel, M., High-level xylanase production from sorghum flour by a newly isolate of Trichoderma harzianum cultivated under solid state fermentation. Annals of Microbiology, 51(1) 61-78 (2001).

Fang, T.J., Liao, B.C. and Lee, S.C., Enhanced production of xylanase by Aspergillus carneus M34 in solid-state fermentation with agricultural waste using statistical approach. New Biotechnology, 27(1), 25-32 (2010).

Farinas, C., Scarpelini, L., Miranda, E. and Neto, V., Evaluation of operational parameters on the precipitation of endoglucanase and xylanase produced by solid state fermentation of Aspergillus niger. Brazilian Journal of Chemical Engineering, 28(1) 17-26 (2011).

Farinas, C.S., Developments in solid-state fermentation for the production of biomass-degrading enzymes for the bioenergy sector. in: Renewable and Sustainable Energy Reviews, 52 179-188 (2015).

Gao, D.H., Uppugundla, N., Chundawat, S.P.S., Yu, X.R., Hermanson, S., Gowda, K., Brumm, P., Mead, D., Balan, V. and Dale, B.E., Hemicellulases and auxiliary enzymes for improved conversion of lignocellulosic biomass to monosaccharides. Biotechnology for Biofuels, 4(5) 1-11 (2011).

Ghanem, N.B., Yusef, H.H. and Mahrouse, H.K., Production of Aspergillus terreus xylanase in solid-state cultures: application of the PlackettBurman experimental design to evaluate nutritional requirements. Bioresource Technology, 73(2) 113121 (2000).

Golunski, S., Astolfi, V., Carniel, N., de Oliveira, D., Di Luccio, M., Mazutti, M.A. and Treichel, H., Ethanol precipitation and ultrafiltration of inulinases from Kluyveromyces marxianus. Separation and Purification Technology, 78(3) 261-265 (2011).
Guimaraes, N.C.D., Sorgatto, M., Peixoto-Nogueira, S.D., Betini, J.H.A., Zanoelo, F.F., Marques, M.R., Polizeli, M. and Giannesi, G.C., Bioprocess and biotechnology: effect of xylanase from Aspergillus niger and Aspergillus flavus on pulp biobleaching and enzyme production using agroindustrial residues as substract. Springerplus, 2 1-7 (2013).

Holker, U. and Lenz, J., Solid-state fermentation - are there any biotechnological advantages? Current Opinion in Microbiology, 8(3) 301-305 (2005).

Kamm, B. and Kamm, M., Principles of biorefineries. Applied Microbiology and Biotechnology , 64(2) 137-145 (2004).

Kumar, R. and Wyman, C.E., Effect of xylanase supplementation of cellulase on digestion of corn stover solids prepared by leading pretreatment technologies. Bioresource Technology , 100(18) 4203-4213 (2009).

Lu, F.X., Lu, M., Lu, Z.X., Bie, X.M., Zhao, H.Z. and Wang, Y., Purification and characterization of xylanase from Aspergillus ficuum AF-98. Bioresource Technology , 99(13) 5938-5941 (2008).

Mandels, M. and Sternberg, D., Recent advances in cellulase technology. Journal of Fermentation Technology, 54(4) 267-286 (1976).

Mander, P., Choi, Y.H., Pradeep, G.C., Choi, Y.S., Hong, J.H., Cho, S.S. and Yoo, J.C., Biochemical characterization of xylanase produced from Streptomyces sp CS624 using an agro residue substrate. Process Biochemistry, 49(3) 451-456 (2014).

Marino, M.A., Freitas, S. and Miranda, E.A., Ethanol precipitation of glycosyl hydrolases produced by Trichoderma harzianum P49P11. Brazilian Journal of Chemical Engineering, 32(2) 325-333 (2015).

Michelin, M., Peixoto-Nogueira, S.C., Betini, J.H.A., da Silva, T.M., Jorge, J.A., Terenzi, H.F. and Polizeli, M., Production and properties of xylanases from Aspergillus terricola Marchal and Aspergillus ochraceus and their use in cellulose pulp bleaching. Bioprocess and Biosystems Engineering , 33(7) 813-821 (2010).

Miller, G., Use of dinitrosalicylic acid reagent for determination of reducing sugar. Analytical Chemistry, 31(3) 426-428 (1959).

Nakadai, T. and Nasuno, S., Enzyme preparation from extract of wheat bran koji by alcohol precipitation. Journal of Fermentation and Bioengineering, 67(4) 253-257 (1989). 
Ninawe, S., Kapoor, M. and Kuhad, R.C., Purification and characterization of extracellular xylanase from Streptomyces cyaneus SN32. Bioresource Technology , 99(5) 1252-1258 (2008).

Park, Y.S., Kang, S.W., Lee, J.S., Hong, S.I. and Kim, S.W., Xylanase production in solid state fermentation by Aspergillus niger mutant using statistical experimental designs. Applied Microbiology and Biotechnology , 58(6) 761-766 (2002).

Pauly, M., Gille, S., Liu, L.F., Mansoori, N., de Souza, A., Schultink, A. and Xiong, G.Y., Hemicellulose biosynthesis. Planta, 238(4) 627-642 (2013).

Pirota, R., Tonelotto, M., Delabona, P.D., Fonseca, R.F., Paixao, D.A.A., Baleeiro, F.C.F., Neto, V.B. and Farinas, C.S., Enhancing xylanases production by a new Amazon Forest strain of Aspergillus oryzae using solid-state fermentation under controlled operation conditions. Industrial Crops and Products, 45 465-471 (2013).

Polizeli, M., Rizzatti, A.C.S., Monti, R., Terenzi, H.F., Jorge, J.A. and Amorim, D.S., Xylanases from fungi: properties and industrial applications. Applied Microbiology and Biotechnology , 67(5) 577-591 (2005).
Saha, B.C., Hemicellulose bioconversion. Journal of Industrial Microbiology \& Biotechnology , 30(5) 279-291 (2003).

Santos, F. A.; Queiróz, J. H.; Colodette, J. L.; Fernandes, S. A.; Guimarães, V. M.; and Rezende, S. T., Potencial da palha de cana-de-açúcar para produção de etanol. Química Nova, 35(5) 10041010 (2012).

Shallom, D. and Shoham, Y., Microbial hemicellulases. Current Opinion in Microbiology , 6(3) 219-228 (2003).

Varma, R.J., Nene, S., Baliga, B.A. and Elias, C., Studies on commercial aspects of xylanase from Chainia species. Journal of Scientific \& Industrial Research, 58(11) 878-882 (1999).

Venegas, I.M., Fuentes-Hernandez, J., Garcia-Rivero, M. and Martinez-Trujillo, A., Characteristics of Aspergillus niger xylanases produced on rice husk and wheat bran in submerged culture and solidstate fermentation for an applicability proposal. International Journal of Food Science and Technology, 48(9) 1798-1807 (2013).

Wong, K.K.Y., Tan, L.U.L. and Saddler, J.N., Multiplicity of beta-1,4-xylanase in microorganisms - functions and applications. Microbiological Reviews, 52(3) 305-317 (1988). 